\title{
METODE PERHITUNGAN SATUAN UNIT PRODUKSI (SUP) DAN INDEKS KONVERSI
}

\section{CALCULATION METHOD OF PRODUCTION UNIT AND THE CONVERSION INDEX}

\author{
Yulianta \\ Pusat Teknologi Industri dan Sistem Transportasi \\ Deputi Teknologi Industri Rancang Bangun dan Rekayasa, BPPT \\ Gedung Teknologi II (251), Lt. 2, Puspiptek Serpong, Tangerang Selatan, Banten \\ Telp. 021-75875944 \\ E-mail : antayul@yahoo.com
}

\begin{abstract}
Abstrak
Kebijakan tarif jasa angkutan Angkutan Sungai, Danau dan Penyebrangan (ASDP) harus diterapkan secara proporsional dan seadil-adilnya kepada setiap muatan berupa penumpang maupun kendaraan dan barang yang ada di atasnya. Prinsipnya adalah semakin banyak sebuah muatan menggunakan sumberdaya maka akan semakin tinggi charge yang dikenakan. Indeks konversi yang dijadikan dasar perhitungan tarif perlu dikaji ulang setelah berlangsung lebih dari 10 tahun. $\mathrm{Hal}$ ini dilakukan karena adanya perubahan dimensi kendaraan yang berpengaruh terhadap penerapan tarif. Selain itu sistem tarif dan satuan yang dipakai di ASDP berbeda dari moda angkutan lain yang berlaku di dunia jasa angkutan. Untuk itu agar selaras perlu dilakukan dasar perhitungan dengan metode yang baru. Penyusunan indeks konversi untuk perhitungan tarif ini dilakukan dengan menganalisis hasil pengumpulan data pengukuran fisik langsung terhadap dimensi/ukuran kapal dan fasilitas untuk penumpang serta muatan berupa penumpang dan kendaraan didukung dengan data sekunder terkait. Dari analisis data dihasilkan perhitungan Satuan Unit Poduksi (SUP) penumpang dewasa kelas ekonomi sebagai SUP 'dasar' yang bernilai indeks 1 (satu) dalam satuan kubik (m3). Muatan berupa kendaraan berdasar dimensi/ukuran masing-masing diformulasikan kemudian dikonversikan terhadap SUP 'dasar' tersebut guna memperoleh besaran SUP masing-masing. Hasilnya dari kendaraan terkecil golongan I besaran SUPnya $=2,36$ hingga kendaraan golongan IX dengan besaran SUP $=171,68$ (kosong) dan 289,77 (isi). Indeks konversi dengan metode ini bisa mengurangi sisi lemah dari metode sebelumnya sekaligus bisa selaras dengan sistem tarif yang lazim diterapkan pada dunia jasa pengangkutan oleh perusahaanperusahaan multinasional.
\end{abstract}

Kata kunci : Satuan Unit Produksi (SUP), Indeks Konversi, Tarif

\begin{abstract}
ASDP freight tariff policy should be applied proportionately and fairly as possible to each passenger and a cargo vehicle and the items on it. The principle is that the more a resource loads using the higher charge will apply. The conversion Index that is used as the basis for calculating tarifhas to be reviewed the last more than 10 years. This is because of vehicle dimension charge that effects tarif. In addition to the tariff system and the unit used in ASDP different from other transport modes prevailing in world freight services. For that to be done in harmony with the basic calculation that the new method. Indexing the conversion rate for the calculation is done by analyzing the results of a direct physical measurement data collection on dimensions/sizes of ships and facilities for passengers and cargo in the form of passengers and vehicles powered by the relevant secondary data. From the analysis of the data calculation generated production Unit (SUP), adult passengers
\end{abstract}


in economy class as SUP 'base' value- index 1 (one) in a cubic unit (m3) . A charge based on vehicle dimensions/size of each of them later converted to SUP 'base' in order to obtain the magnitude of SUP, respectively. The results of the smallest vehicle class I have SUP of 2.36 to vehicle classes IX to scale SUP of 171.68 (empty) and 289.77 (loaded). Conversion index with this method can reduce the weak side of the previous methods could well aligned with a common tariff system applied to the world's transportation services by multinational corporations

Key Words : Production Unit, conversion index, Tariff

Diterima (received) : 2 Juni 2014, Direvisi (reviewed) : 10 Juni 2014,

Disetujui (accepted) : 2 Juli 2014

\section{PENDAHULUAN}

Salah satu prinsip kebijakan yang dilakukan pemerintah dalam penetapan tarif jasa angkutan penyeberangan sejauh mungkin adalah mengenakan tarif kepada setiap muatan berupa penumpang maupun kendaraan beserta barang yang ada di atasnya dengan proporsional dan seadil-adilnya. Prinsipnya adalah semakin banyak sebuah muatan menggunakan sumberdaya maka akan semakin tinggi tarif atau ongkos yang harus ditanggungnya. Tarif sebuah bus besar akan berbeda dengan sepeda motor, truk tronton berisi penuh muatan di atasnya berbeda charge-nya dengan mobil pick-up kosong tanpa muatan atau dengan penumpang pejalan kaki. Bagaimana metode perhitungan dan pembebanan charge terhadap setiap muatan yang jenis dan ukurannya cukup beragam tersebut?

Pedoman dalam menentukan besaran tarif angkutan salah satunya adalah dengan menyusun indeks konversi, sebagaimana yang dipergunakan saat ini. Perhitungan tarif jasa ASDP yang saat ini berlaku berdasarkan indeks konversi hasil survei tahun 2001. Setelah berlangsung lebih dari 10 tahun, dirasa perlu untuk dikaji ulang ketepatan dasar-dasar perhitungan indeks konversi tersebut. Hal ini antara lain disebabkan adanya ketidakselarasan sistem tarif dimana sistem dan satuan yang dipakai di ASDP berbeda dari moda angkutan lainnya yang berlaku di dunia jasa angkutan. Selain itu telah terjadinya perubahan terutama dimensi/ukuran kendaraan/daya muat yang sangat berpengaruh dalam penyusunan tarif angkutan penyeberangan sehingga sangat dimungkinkan terjadi ketidaktepatan pengenaan sasaran tarif dikarenakan terjadinya ketidaksesuaian lagi antara tarif angkutan penyeberangan dengan ukuran/dimensi kendaraan yang sesungguhnya. Selain itu perhitungan tarif jasa angkutan kapal sebagaimana yang berlaku di dunia internasional menggunakan satuan berbasis berat $(\mathrm{kg})$ dan kubikasi $\left(\mathrm{m}^{3}\right)$.
Demikian juga dengan angkutan udara. Sementara tarif muatan di atas kapal-kapal ASDP menggunakan satuan berbasis luas yakni meter persegi $\left(\mathrm{m}^{2)}\right.$.

Berdasarkan kondisi tersebut makaperlu dilakukan penyempurnaan penyempurnaan melalui metode baru yang bisa ditawarkan sesuai dengan kondisi pada saat ini agar lebih proporsional, adil dan realistis sekaligus selaras dengan standar yang berlaku di dunia internasional.

\section{BAHAN DAN METODE}

Kajian Perhitungan Satuan Unit Produksi (SUP) dan indeks konversi dalam rangka perhitungan tarif angkutan penyeberangan ini ditempuh dengan jenis-jenis kegiatan dan metode : a) Melakukan kajian pustaka b) Tinjauan peraturan perundang-undangan dan kebijakan yang terkait c) Tinjauan studi/kajian sebelumnya d) Pengumpulan data primer yakni observai dan pengukuran fisik serta data sekunder terkait. Pelaksanaan pengumpulan data primer dilakukan dengan metode observasi dan pengukuran fisik langsung terhadap jenis kapal angkutan penyeberangan dan jenis-jenis muatannya serta metode wawancara. Data sekunder yang dibutuhkan meliputi data jumlah muatan, penumpang dan kendaraan, jenis-jenis kendaraan, ukuran berat dan spesifikasi kendaraan lainnya serta data yang menyangkut tarif dan penggolongan kendaraan. e) Benchmarking sistem pentarifan moda angkutan lain, f) Melakukan analisa datag) Melakukan perumusan dengan metode baru Perhitungan Satuan Unit Produksi (SUP) dan indeks konversi untuk perhitungan tarif jasa angkutan penyeberangan.

\section{Tinjuan Regulasi}

Dalam rangka peningkatan pelayanan untuk semua jenis dan golongan kendaraan, telah dilakukan penyesuaian dan penyempurnaan terhadap pengaturan mekanisme penetapan dan formulasi perhitungan tarif angkutan 
penyeberangan, yakni melalui Peraturan Menteri Perhubungan No. 18 Tahun 2012 : Tentang Perubahan Atas Keputusan Menteri Perhubungan Nomor KM. 58 Tahun 2003 tentarig Mekanisme Penetapan dan Formulasi Perhitungan Tarif Angkutan Penyeberangan. ${ }^{4)}$ Penyesuaian/perubahan tersebut berupa penambahan sebagaimana tercantum pada Peraturan Menteri Perhubungan di atas pada Pasal 1. Pada Pasal 2 ayat (4) ditetapkan berdasarkan pembagian menjadi 9 (sembilan) dari semula 8 (delapan) golongan, yakni terdapat tambahan golongan IX : Kendaraan bermotor berupa Mobil barang (truk tronton) $j$ tangki, kendaraan alat berat dan kereta penarik berikut gandengan dengan ukuran panjang lebih dari 16 (enam belas) meter dan sejenisnya. Adapun besaran SUP masingmasing kendaraan adalah kendaraan : Gol. I = 1,6 SUP, Gol. II = 2,8 SUP, Gol. III = 5,6 SUP, Gol.IV ;Kendaraan penumpang beserta penumpangnya $=21,63$ SUP, Kendaraan barang beserta muatannya $=17,98$ SUP, Gol.V; Kendaraan penumpang beserta penumpangnya $=37,39$ SUP, Kendaraan barang beserta muatannya $=31,55$ SUP, Gol.VI; Kendaraan penumpang beserta penumpangnya $=63,28$ SUP, Kendaraan barang beserta muatannya $=52,33$ SUP, Gol. VII Kendaraan barang beserta muatannya = 66,03 SUP, Gol.VIII Untuk barang beserta muatannya $=98,75$ SUP dan Gol. IXUntuk barang beserta muatannya $=148,13$ SUP. ${ }^{6}$ )

\section{Hubungan Indeks Konversi, Tarif dan SUP}

Hubungan Indeks Konversi dan tarif adalah bahwa Indeks Konversi merupakan pedoman atau patokan dasar bagi penetapan besaran tarif. Perhitungan Indeks Konversi didasarkan pada data-data teknis, sedangkan perhitungan tarif didasarkan pada pembentukkan biaya pokok dari biaya operasional kapal. Sedangkan SUP adalah obyek berupa muatan yang akan dikenai tarif.

Berkenaan dengan karakteristik setiap lintasan, jarak lintasan, tipe dan ukuran kapal, kecepatan kapal, daya dukung, dan daya beli masyarakat setempat, kondisi dan sifat pelabuhan yang berbeda-beda, pemerintah dengan berbagai pertimbangan dapat membuat kebijakan tarif yang dilandasi pertimbangan ekonomi, politik dan sosial dan hal ini telah berlaku selama ini.

\section{Evaluasi Perhitungan SUP dan Indeks Konversi Studi Sebelumnya}

Terdapat beberapa catatan dengan mencermati perhitungan dan perumusan SUP dan indeks konversi baik hasil Kajian tahun 2001 maupun Indeks konversihasil Kajian 1990 bahwa muatan disebut produksi dan setiap muatan yang beraneka jenis (penumpang, kendaraan dan barang di atas kendaraan) dan ukurannya disebut Unit Produksi dan setiap satuan dari unit muatan / unit produksi tersebut disebut Satuan Unit Produksi (SUP).Pendekatan yang digunakan dalam mengukur setiap unit muatan (unit produksi) baik penumpang maupun kendaraan adalah menggunakan pendekatan luasan (dimensi : panjang x lebar) dan satuan ukuran yang digunakan mengukur SUP adalah menggunakan satuan meter persegi (m2).Satuan Unit Produksi (SUP) yang dijadikan dasar perhitungan (Indeks $=1$ ) adalah Penumpang Dewasa Kelas Ekonomi. Satuan Unit Produksi (SUP) didefinisikan sebagai :Satuan luas $\left(\mathrm{m}^{2}\right)$ yang diperlukan 1 (satu) orang penumpang kelas Deck / Ekonomi dengan standar pelayanan minimal, yang nilainya sama dengan 1 (satu) SUP. ${ }^{2)}$

Luasan SUP Penumpang Dewasa Kelas Ekonomi tersebut berdasar perhitungan Kajian Tahun 1990 adalah $0,70 \mathrm{~m}^{2}$ 2) sedangkan berdasar perhitungan Kajian Tahun 2001 adalah sebesar $0,73 \mathrm{~m}^{2}$. Angka $0,73 \mathrm{~m}^{2}$ pada Kajian 2001 adalah luas ruang meliputi : Luas ruangan yang tersedia untuk kursi, jarak antara kursi ke samping, depan - belakang, fasilitas seperti AC, TV/Video/Soundsystem, Kantin, Toilet, Panggung hiburan dan lain-lain. Perhitungan SUP untuk kendaraan dihitung berdasarkan Pemakaian ruang kendaraan meliputi: Luas ruangan yang ditempati kendaraan itu sendiri dan jarak antara kendaraan ke depan / belakang, kekiri dan kekanan.

\section{Alur Pikir Analisis}

Dalam proses mendapatkan indeks konversi untuk perhitungan tarif jasa angkutan penyeberangan, maka disamping dilakukan dengan pendekatan peraturan perundangundanganjuga dipadukan dengan pendekatan analisis data sekunder dan hasil survey yang dilakukan serta hubungan antar variabel. Alur pikir kajian ini ditampilkan pada Gambar 1 .

Data sekunder yang dibutuhkan meliputi data jumlah muatan, penumpang dan kendaraan, jenis-jenis kendaraan, ukuran berat dan spesifikasi kendaraan lainnya serta data 


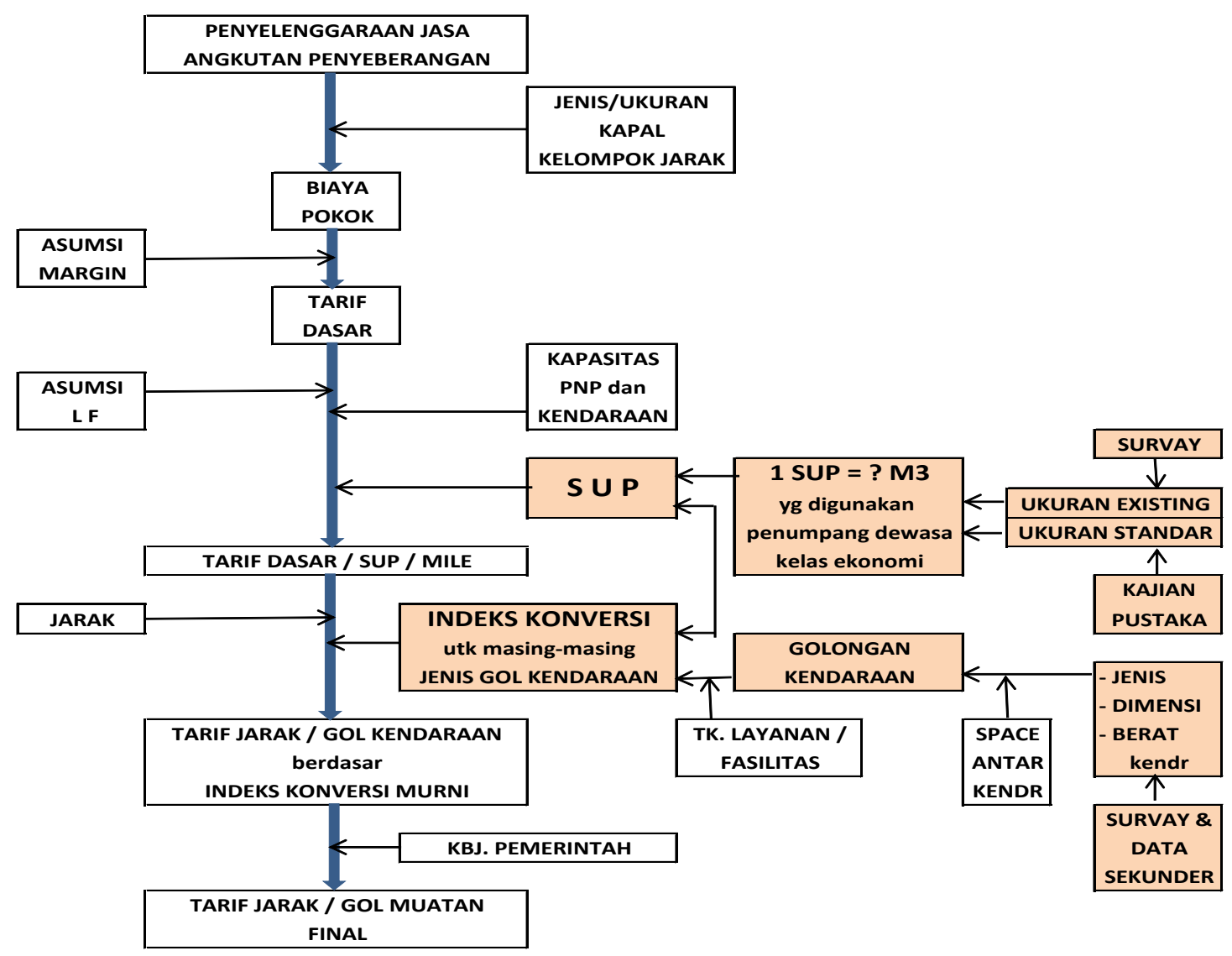

Gambar 1.

Alur Pikir Kajian Indeks Konversi

yang menyangkut tarif dan penggolongan kendaraan serta survei pengukuran dimensi kendaraan.

Data sekunder yang dibutuhkan meliputi data jumlah muatan, penumpang dan kendaraan, jenis-jenis kendaraan, ukuran berat dan spesifikasi kendaraan lainnya serta data yang menyangkut tarif dan penggolongan kendaraan. Survei yang dimaksud meliputi survey muatan khususnya kendaraan untuk dilakukan pengukuran dimensi kendaraan.

\section{HASIL DAN PEMBAHASAN \\ Kondisi Sarana dan Muatan Angkutan Penyeberangan}

Sarana Angkutan Penyeberangan. Hasil penulusuran data sekunder dan data primer pada lintas-lintas dimana survai dilakukan disajikan dengan 1 (satu) contoh spesifikasi dan hasil pengukuran kapal penyeberangan KMP. Muriasebagai berikut :

Kursi : a)Jumlah Kursi $=235$ kursi ; b) Jenis kursi $=$ Fiberglass $; \mathrm{c}$ ) Dimensi kursi : Luas kursi $(p \times I)=53,0 \mathrm{~cm} \times 46,0 \mathrm{~cm}$; Tinggi kursi $=41,0 \mathrm{~cm} ;$ Jarak antar kursi depan/belakang $=32,0 \mathrm{~cm} ;$ Jarak antar kursi kanan $/$ kiri $=7,0$ $\mathrm{cm}$

Fasilitas Penumpang Ekonomi : a) Toilet $=$ $7,69 \mathrm{~m}^{2}$; Kantin $=4,79 \mathrm{~m} 2$; Audio/video $=1,38 \mathrm{~m}^{2}$; Mushola $=$ ada $;$ Gang $=58,50 \mathrm{~cm}$. Dengan demikian luas total ruang penumpang ekonomi $=179 \mathrm{~m} 2$

Adapun contoh hasil penelusuran data sekunder dari PT. ASDP, tentang data kapasitas penumpang dan kendaraan serta luas ruangan kapal untuk penumpang dan kendaraan disajikan pada Tabel 1, sedangkan contoh obyek pengukuran ruang tempat duduk penumpang dan kendaraan disajikan pada Gambar 2 dan Gambar 3. 
Tabel 1.

Kapasitas dan Ruangan Kapal untuk Penumpang dan Kendaraan

\begin{tabular}{lccccc}
\hline \multicolumn{1}{c}{ Nama Kapal } & \multicolumn{3}{c}{ Kapasitas } & \multicolumn{3}{c}{ Luas Ruangan Kapal } \\
& GRT & $\begin{array}{c}\text { Pnp } \\
\text { (orang) }\end{array}$ & R4 (unit) & Pnp (m2) & Kend. (m2) \\
\hline KMP. Ile Mandiri & 533 & 200 & 22 & 195,45 & 493,77 \\
KMP. Rokatenda & 526 & 220 & 22 & 184,08 & 418,18 \\
KMP. Balibo & 540 & 242 & 22 & 203,28 & 476,43 \\
KMP. Ile Ape & 634 & 250 & 22 & 184,08 & 431,43 \\
KMP. Uma Kalada & 881 & 237 & 22 & 203,84 & 477,00 \\
KMP. Cucut & 530 & 129 & 22 & 184,04 & 441,56 \\
KMP. Namparnos & 167 & 54 & 7 & 62,06 & 223,41 \\
JUMLAH & 3.811 & 1.332 & 139 & $1.216,83$ & $2.961,78$ \\
\hline PT. ASDP Cabang Kupang 2012) & \multicolumn{5}{c}{}
\end{tabular}

PT. ASDP Cabang Kupang 2012

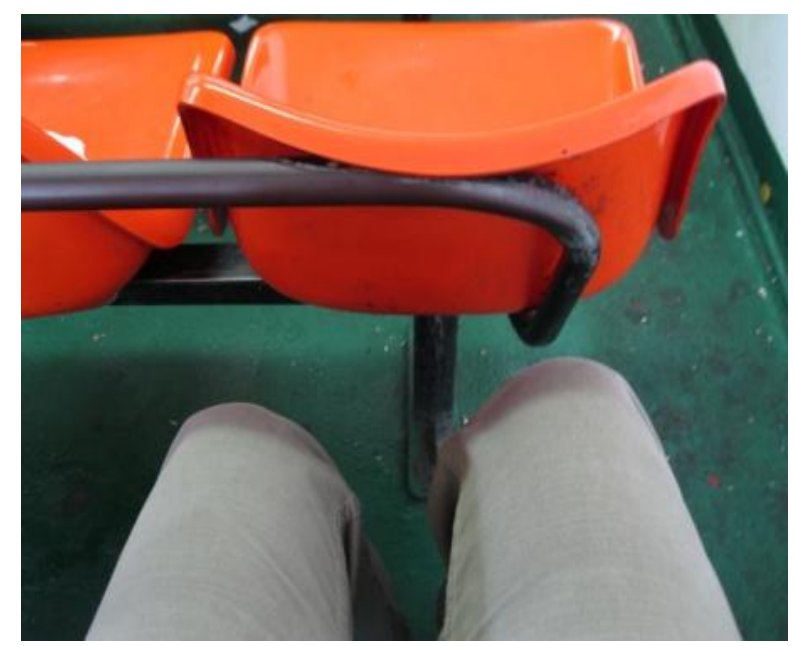

Gambar 2

Ruang tempat duduk penumpang

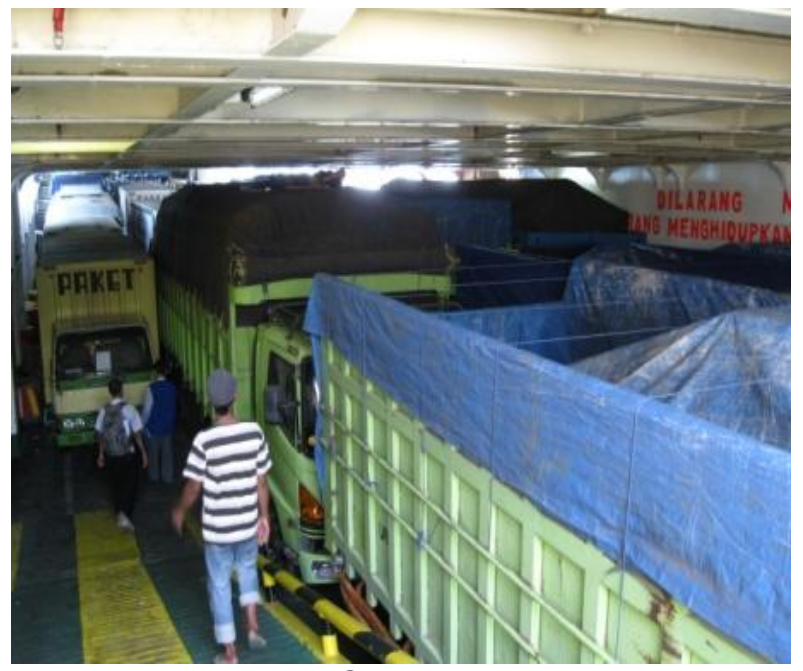

Gambar 3

Ruang Kendaraan 
Data sekunder yang dibutuhkan meliputi data jumlah muatan, penumpang dan kendaraan, jenis-jenis kendaraan, ukuran berat dan spesifikasi kendaraan lainnya serta data yang menyangkut tarif dan penggolongan kendaraan. Survei yang dimaksud meliputi survei muatan khususnya kendaraan untuk dilakukan pengukuran dimensi kendaraan.

\section{Kendaraan sebagai Muatan Angkutan Penyeberangan.}

Survei pengukuran langsung dimensi kendaraan muatan angkutan penyeberangan dilakukan terhadap kendaraan-kendaraan baik di atas kapal maupun saat kendaraan parkir di pelabuhan penyeberangan. Pengukuran berbagai jenis kendaraan dari golongan I hingga golongan IX, mencakup panjang, lebar dan tinggi kendaraan.

Adapun survai pengukuran langsung terhadap jarak antar kendaraan, yakni ke samping, kedepan dan ke belakang dilakukan di atas kapal terhadap kendaraan Roda 2 dan kendaraan Roda 3 dan Roda 4 (sepeda motor). Hasil pengukuran : Range jarak ke samping $=14 \mathrm{~cm}-58 \mathrm{~cm}$ (Roda-4) dan $9 \mathrm{~cm}$ - $39 \mathrm{~cm}$ (Roda-2/Roda-3), sedangkan range jarak ke depan dan ke belakang $=14 \mathrm{~cm}-$ $101 \mathrm{~cm}$ (Roda-4) dan - (minus) $\mathrm{cm}-6 \mathrm{~cm}$ (Roda-2/Roda-3).

\section{Benchmarking Penerapan Perhitungan Berat dan Volume Muatan}

Penetapan tarif angkutan yang berlaku di lingkungan ASPERINDO dan yang berlaku dan diterima luas yang dipergunakan oleh perusahaan-perusahaan multinasional, dalam melakukan perhitungan berat barang menggunakan dua jenis cara perhitungan yakni perhitungan berat sesungguhnya dan berat volume. Adapun penerapan rumus yang digunakan untuk pengiriman barang yang berlaku di lingkungan ASPERINDO adalah :Via darat adalah $=$ Panjang $(\mathrm{cm}) \times$ Lebar $(\mathrm{cm}) X$ Tinggi $(\mathrm{cm}): 4000$; Via udara adalah $=$ Panjang $(\mathrm{cm}) X$ Lebar $(\mathrm{cm}) X$ Tinggi $(\mathrm{cm}): 6.000$; Via laut adalah= Panjang $(\mathrm{cm})$ X Lebar $(\mathrm{cm}) \mathrm{X}$ Tinggi $(\mathrm{cm}): 1.000 .000=\mathrm{M}^{3}$ (kubikasi). Adapun penerapan Rumus yang Digunakan untuk Pengiriman Barang Via Jasa Internasional DHL, FedEx, TNT dan UPS adalah $=$ Panjang $(\mathrm{cm}) X$ Lebar $(\mathrm{cm}) X$ Tinggi $(\mathrm{cm}): 5.000$.

\section{Konsep Perhitungan SUP}

Guna mengurangi sisi kekurangan dari metode pengukuran SUP dengan menggunakan dimensi luasan ( Panjang $x$ Lebar = Luas) ruangan yang dibutuhkan masing-masing jenis/golongan muatan maka dalam kajian ini diusulkan dengan menggunakan pendekatan perhitungan dengan dimensi Volume / Kubikasi. Yakni $\mathrm{m}^{3}$ ruangan yang digunakan oleh masing-masing jenis/golongan muatan, dimana selain dimensi panjang dan lebar juga diperhitungkan tingginya sehingga rumusannya menjadi : Panjang $x$ Lebar $x$ Tinggi $=$ Volume $\left(\mathrm{m}^{3}\right)$.

\section{Tahap Perhitungan Satuan Unit Produksi (SUP)}

Langkah Pertama adalah penghitungan SUP untuk setiap jenis/golongan muatan adalah menjadikan salah satu dari jenis/golongan muatan menjadi SUP Dasar dimana SUP Dasar ini akan dijadikan SUP yang ber-INDEKS $=1$. Dan penumpang dewasa kelas ekonomi yang dipilih sebagai SUP Dasar. Kedua, adalah menentukan aspek-aspek dan unsur-unsur yang diperhitungkan dalam perhitungan SUP Dasar tersebut, demikian juga perhitungan untuk kendaraan. Aspek-aspek yang diperhitungkan dalam metode ini adalah : Penumpang, kendaraan dan muatan.

Volume ruangan kapal yang tersedia untuk penumpang dewasa kelas ekonomi. Volume ruangan tersebut meliputi :

1. Ruangan yang tersedia untuk kursi/tempat duduk,

2. Jarak antara kursi ke samping, depan belakang dan

3. Fasilitas seperti ;Musholla, AC, TV/Video/Soundsystem, Kantin, Toilet, Gang, Panggung hiburan dan lain-lain.

Sedangkan unsur-unsur yang diperhitungkan dalam SUP Dasar adalah :

1. Tubuh penumpang dewasa kelas ekonomi,

2. Kursi/tempat duduk,

3. Fasilitas,

4. Area bebas (vertikal dan horizontal) dan

5. Barang tentengan.

Ketiga, untuk tujuan penyederhanaan perhitungan diperlukan pembatasan dengan membangun asumsi-asumsi. Dalam perhitungan SUP Dasar ini asumsiasumsinya adalah sebagai berikut : 


\section{Unsur Penumpang}

1. Tubuh Penumpang. Tinggi rata-rata penumpang dewasa kelas ekonomi adalah $160 \mathrm{~cm}^{8)}$. Sedangkan berat ratarata penumpang dewasa kelas ekonomi adalah $62 \mathrm{~kg}$ atau 137 pon $^{5}$. Adapun berat jenis tubuh manusia adalah 759 $\mathrm{Kg} / \mathrm{m}^{11}$.

2. Kursi/Tempat Duduk. Berat kursi / tempat duduk per penumpang dewasa kelas ekonomi rata-rata adalah $5 \mathrm{~kg}$ dan berat jenis kursi /tempat duduk bersama fasilitas lain rata-rata $1000 \mathrm{~kg} / \mathrm{m}^{3}$.)

3. Fasiltas. Berat seluruh fasilitas per penumpang dewasa kelas ekonomi ratarata adalah $3 \mathrm{~kg}$ dan berat jenis berbagai fasilitas penumpang rata-rata $1000 \mathrm{~kg} /$ $\mathrm{m}^{3}$.

4. Area Bebas (Vertikal dan Horizontal). Ruang vertikal bebas diperhitungkan sampai dengan setinggi rata-rata penumpang yakni $160 \mathrm{~cm}$. Sedangkan area bebas horizontal ditentukan berdasar hasil survai dan penelusuran data sekunder yakni bersama-sama dengan tubuh penumpang, fasilitas dan jarak kursi adalah $0,78 \mathrm{~m}^{2}$. Berat udara di area bebas adalah $1 \mathrm{~kg}$ (dibulatkan, dalam volume $\left.1,25 \mathrm{~m}^{3}\right)$. $^{3}$ Berat jenis udara di area bebas vertikal dan horizontal dalam volume ruangan yang digunakan oleh penumpang dewasa kelas ekonomi rata-rata sebesar $1,21 \mathrm{~kg} /$ $\mathrm{m}^{3}$, yakni berdasar tekanan, suhu dan kelembaban udara di Indonesia rata-rata $1,16-1,25 \mathrm{~kg} / \mathrm{m}^{3}$. 9)

5. Barang Tentengan. Berat barang tentengan rata-rata per penumpang dewasa kelas ekonomi adalah $7 \mathrm{~kg}$. (= batasan berat barang tentengan untuk penumpang pesawat domestik kelas ekonomi). Berat jenis barang tentengan penumpang rata-rata $1000 \mathrm{~kg} / \mathrm{m}^{3}$.

6. Share, Berat Jenis dan Berat SUP Dasar. Volume ruang (m3) penumpang dewasa kelas ekonomi yang diperhitungkan terdiri dari beberapa benda fisik dengan share masing-masing sebagai berikut : Tubuh penumpang $=25$ $\%$; Kursi, Fasilitas, Barang tentengan = $25 \%$; Udara di area bebas vertikal \& horizontal $=50 \% .{ }^{3)}$ Dengan komposisi tersebut maka rata-rata berat jenis keseluruhan adalah : Tubuh penumpang $(759,23 \times 1)=759,23 \mathrm{~kg} / \mathrm{m}^{3} ;$ Kursi, Fasilitas, Barang tentengan $(1.000,00 \mathrm{x}$ 1) $=1.000,00 \mathrm{~kg} / \mathrm{m}^{3} ;$ Udara $(1,21 \times 2)=$ $2,41 \mathrm{~kg} / \mathrm{m}^{3}$. Dengan demikian total $=$
$1.761,64 \mathrm{~kg} / \mathrm{m} 3$. Sehingga berat Jenis Rata-rata $(1.761,64: 4)=440,41 \mathrm{~kg} / \mathrm{m}^{3}$.

7. Berat SUP Dasar yang Disesuaikan. Diasumsikan berat jenis berbagai macam barang muatan yang akan dikonversikan rata-rata sebesar $1.000 \mathrm{~kg} / \mathrm{m}^{3}{ }^{3)}$ Dengan demikian maka berat SUP Dasar yang telah disesuaikan = Berat SUP Dasar $\mathrm{x}$ ( $1000 \mathrm{~kg} / \mathrm{m}^{3}: 440,41 \mathrm{~kg} / \mathrm{m}^{3}$ ).

\section{Unsur Kendaraan}

Perhitungan SUP untuk kendaraan dihitung berdasarkan Pemakaian ruang kendaraan meliputi volume :Ruangan yang ditempati kendaraan itu sendiri dan jarak antar kendaraan ke depan / belakang, kekiri dan kekanan.

Asumsi-asumsi yang dibangun dalam perhitungan SUP Kendaraan ini adalah sebagai berikut :Untuk kendaraan penumpang isi penumpang, jumlah penumpang diperhitungkan $60 \%$ dari kapasitas muatnya ; Untuk perhitungan setiap jenis kendaraan umum penumpang dan kendaraan barang otomatis ditambahkan 2 (dua) SUP Dasar sebagai pembebanan untuk sopir dan kenek/kondektur ; Jarak antar kendaraan Roda-4 atau lebih ke depanbelakang masing-masing $15 \mathrm{~cm}$ dan kekiri kekanan masing-masing $30 \mathrm{~cm}$.Jarak antar kendaraan Roda-2 dan Roda-3 ke samping masing-masing $10 \mathrm{~cm}$ dan ke depan/belakang rata-rata $0 \mathrm{~cm}^{3)}$

\section{Unsur Muatan}

Asumsi-asumsi yang dibangun dalam perhitungan SUP muatan adalah sebagai berikut :Berat Jenis barang muatan rata-rata sebesar $1.000 \mathrm{~kg} / \mathrm{m} 3$; Untuk kendaraan barang isi muatan, berat muatannya diperhitungkan sama dengan (100\%) berat kapasitas muatnya ; Untuk kendaraan penumpang isi, jumlah penumpang diperhitungkan $60 \%$ dari jumlah kapasitas muatnya.

Keempat, melakukan perhitungan dimensi untuk setiap jenis golongan muatan berdasar hasil pengukuran langsung di lapangan, penelusuran data sekunder, hasil benchmarking ataupun referensi kajian pustaka yang telah dikumpulkan ke dalam bentuk satuan volume / kubikasi.

Konsep Perumusan Indeks Konversi Baru. Dalam motode/pendekatan perhitungan SUP muatan angkutan penyeberangan untuk masing-masing jenis/golongan muatan sebagaimana diulas pada perhitungan di atas bahwa penumpang dewasa kelas ekonomi 
dijadikan sebagai SUP Dasar dan ini merupakan SUP berindeks 1. Jenis/golongan muatan lainnya yakni yang berjenis kendaraan dari berbagai golongan dengan besaran SUP masing-masing dari hasil perhitungan sebelumnya, selanjutnya dikonversikan terhadap SUP Dasar tersebut. Hasil dari pengonversian tersebut adalah berupa besaran indeks untuk masing-masing golongan tersebut. Adapun untuk perhitungan indeks dilakukan melalui pengonversian dari SUP masing-masing jenis / golongan muatan ke SUP Dasar dengan formula sebagai berikut $^{3)}$ :

1. Penumpang

$$
\text { Penumpang dewasa ekonomi }=\frac{\text { Vol.Penumpang Dewasa }}{\text { Vol.SUP Dasar }}
$$

2. Kendaraan R-2 dan R-3

3. a. Kendaraan R-2 Kosong

$$
\text { Kendaraan R-2 kosong Golongan y }=\left(\frac{\text { Vol.Kendaraan Gol.y }}{\text { Vol.SUP Dasar }}\right)+1 \text { SUP Dasar }
$$

b. Kendaraan R-2 Isi

Kendaraan R-2 isi Golongan y $=\left(\frac{\text { Vol.Kendaraan Gol.y }}{\text { Vol.SUP Dasar }}\right)+2$ SUP Dasar

c. Kendaraan R-3 Kosong

Kendaraan R-3 kosong Golongan y $=\left(\frac{\text { Vol.Kendaraan Gol.y }}{\text { Vol.SUP Dasar }}\right)+1$ SUP Dasar

d. Kendaraan R-3 Isi

Kendaraan R-3 kosong

Golongan $\mathrm{y}=\left(\frac{\text { Vol.Kendaraan Gol.y }}{\text { Vol.SUP Dasar }}\right)+1$ SUP Dasar +

$$
\left(\frac{\text { Brt isi kend.-Brt kosong kend Gol y }}{\text { Berat SUP Dasar }}\right)+\text { SUP Dasar(2d) }
$$

4. Kendaraan Penumpang

a. Kendaraan Penumpang Kosong

Kendaraan Penumpang Kosong

Golongan $y=\left(\frac{\text { Vol.Kendaraan Gol.y }}{\text { Vol.SUP Dasar }}\right)+2$ SUP Dasar

b. Kendaraan Penumpang Isi

Kendaraan Penumpang Isi

$$
\begin{aligned}
& \text { Golongan } \quad y=\left(\frac{\text { Vol.Kend. Gol.y }}{\text { Vol.SUP Dasar }}\right)+2 \text { SUP Dasar } \\
& \left(\frac{60 \text { x kapasitas penumpang gol y }}{100}\right) \times \text { SUP Dasar }
\end{aligned}
$$

5. Kendaraan Barang

a. Kendaraan Barang Kosong

Kendaraan Barang Kosong

Golongan $y=\left(\frac{\text { Vol.Kendaraan Gol.y }}{\text { Vol.SUP Dasar }}\right)+2$ SUP Dasar 
b. Kendaraan Barang Isi

Kendaraan Barang Isi

Golongan y $=\left(\frac{\text { Vol.Kend. Gol.y }}{\text { Vol.SUP Dasar }}\right)+2$ SUP Dasar +

$\left(\frac{\text { Berat isi kend.-Berat kosong kend.gol y }}{\text { Berat SUP Dasar }}\right) \times$ SUP Dasar

Luas ruangan kapal yang dibutuhkan untuk penumpang dewasa kelas ekonomi adalah sebesar $0,78 \mathrm{~m}^{2}$.

Tinggi rata-rata penumpang dewasa kelas ekonomi adalah 1,60 m. Pria Indonesia kelahiran tahun 60-an kebawah rata-rata tingginya adalah $165 \mathrm{~cm}$, sedangkan wanitanya adalah $155 \mathrm{~cm}{ }^{8)}$

Volume ruangan kapal yang dibutuhkan untuk penumpang dewasa kelas ekonomi besaran-besaran ; luas, tinggi, volume, dan berat berdasarkan hasil pengukuran dan perhitungan diperoleh hasil sebagai berikut : sebesar : $1,25 \mathrm{~m}^{3}$ yakni dari perhitungan : $0,78 \mathrm{~m} \times 1,60 \mathrm{~m},=1,25 \mathrm{~m} 3$.

Berat penumpang dewasa ekonomi beserta unsur-unsur melekat (SUP Dasar) yang diperhitungkan rata-rata : $77 \mathrm{~kg}$, sebagaimana hasil perhitungan dari tabel berikut : Tubuh penumpang $=62 \mathrm{~kg} ;$ Kursi $=4$ $\mathrm{kg}$; Fasiltas $=3 \mathrm{~kg}$; Udara di area bebas $=1$ $\mathrm{kg}$ dan barang tentengan $=7 \mathrm{~kg}$. Jadi berat total $=77 \mathrm{~kg}$.

Untuk kepentingan peng-konversi-an (volume SUP Dasar dengan volume barang muatan) maka berat nominal tersebut harus disesuaikan dengan memperhitungkan berat jenis masing-masing. Berdasar hasil perhitungan-perhitungan di atas maka berat SUP Dasar yang disesuaikanbisa dihitung: Berat SUP Dasar x $\left(1000 \mathrm{~kg} / \mathrm{m}^{3}: 440,41\right.$ $\left.\mathrm{kg} / \mathrm{m}^{3}\right)=77 \mathrm{~kg} \quad x \quad\left(1000 \mathrm{~kg} / \mathrm{m}^{3}: 440,41\right.$ $\left.\mathrm{kg} / \mathrm{m}^{3}\right)=174,84 \mathrm{~kg}$.

Studi tahun 2001, dengan rekomendasi tidak memperhitungkan berat muatan untuk mengurangi ekses negatif dari aktivitas penimbangan berat di satu sisi memiliki kepraktisan dan keserderhanaan sistem tarif. Namun dengan tidak memperhitungkan berat, sisi lainnya terdapat pengurbanan aspek keadilan dan memicu tingkat kerusakan sarana/prasarana yang lebih besar dari kecenderungan overload,

Terdapat perbedaan antara hasil kajian tahun 1990, kajian tahun 2001 dan kajian tahun 2012. Perbedaan tersebut menyangkut metode/pendekatan dimana kajian tahun 1990 dan 2001 menggunakan luasan $\left(\mathrm{m}^{2}\right)$ sebagai dasar perhitungan, sementara kajian tahun 2012 menggunakan satuan volume/kubikasi $\left(\mathrm{m}^{3}\right)$. Dengan menggunakan volume maka selain satuan luas juga diperhitungkan faktor tinggi muatan, sehingga golongan kendaraan yang memiliki ketinggian lebih dari tinggi tubuh penumpang dewasa kelas ekonomi (yang dijadikan SUP Dasar) akan cenderung terkena pembebanan SUP yang lebih besar dan sebaliknya.

Metode perhitungan yang diterapkan pada kajian tahun 2012 tetap memiliki kepraktisan dan keserderhanaan sistem tarif sebagaimana metode yang diterapkan dalam kajian tahun 2001. Perbedaannya adalah unsur berat muatan tidak (bisa) langsung dikonversikan/ diperhitungkan dalam metode/pendekatan kajian tahun 1990 dan 2001 sementara dengan perhitungan dan asumsi tertentu berat muatan bisa langsung dikonversikan/diperhitungkan dalam kajian tahun 2012.

Metode yang digunakan dalam kajian tahun 2012 dengan menggunakan satuan kubikasi/volume menghasilkan sistem perhitungan yang lazim diterapkan di dunia pengangkutan yang menggunakan kapal sebagai alat angkut. Perbedaannya hanya faktor berat dan volume digunakan secara bersama-sama di dunia angkutan kargo dimana yang lebih besarlah yang akan dipilih setelah melalui pengukuran/penimbangan. Sedangkan pada angkutan penyeberangan berat muatan langsung dikonversikan ke dalam kubikasi/volume tanpa dilakukan penimbangan terlebih dahulu.

\section{SIMPULAN}

Dari hasil kajian ini dapat disampaikan bahwa penggunaan metode atau pendekatan perhitungan dengan menggunakan dimensi volume/kubikasi akan memberikan pembebanan yang lebih adil dan proporsional kepada setiap jenis/golongan muatan, yakni selain memperhitungkan volume ruangan juga memperhitungkan berat muatan. Hal ini lebih realisitis mengingat semua angkutan baik darat, laut maupun udara demi aspek keselamatan dan penghindaran kerusakan harus memperhatikan berat beban kendaraan dan muatan. 
Dalam praktek yang lazim dilakukan di dunia pengangkutan yang menggunakan sarana kapal baik nasional maupun internasional perusahaan-perusahaan multinasional menggunakan formula perhitungan muatan dengan ukuran volume/ kubikasi atau berat muatan secara bersamasama, bukan menggunakan dimensi luas $\left(\mathrm{m}^{2}\right)$.

Dengan metode pendekatan dimensi volume/kubikasi dimana berat dengan perhitungan tertentu bisa dikonversikan ke dalam volume/kubikasi maka di luar kepentingan aspek keselamatan, fasilitas alat timbang bukan menjadi prioritas yang mendesak.

\section{UCAPAN TERIMA KASIH}

Kajian ini banyak mengambil manfaat dari studi yang diselenggarakan oleh Direktorat Lalu-lintas Angkutan Sungai, Danau dan Penyebrangan (LLASDP) Kemenhub Tahun 2012.

\section{DAFTAR PUSTAKA}

1. Clarys dan Jones Marfeel dalam Noor A. Yudha dkk, Berat Jenis Tubuh Manusia,_, 2012.

2. Departemen Perhubungan, Indeks Konversi Baru/Kajian 2001 sebagai Dasar Penyusunan Tarif Angkutan Penyeberangan, Jakarta, 2001

3. Kementerian Perhubungan, Kajian Indeks Konversi untuk Perhitungan Tarif Jasa Angkutan Penyeberangan, Jakarta, 2012.

4. Keputusan Menteri Perhubungan Nomor KM.58, 2003.

5. _, _, London School of Hygiene of Tropical Medicine.

6. Peraturan Menteri Perhubungan No.18, 2012.

7. PT. ASDP (Persero) Cabang Kupang, 2012.

8. _, Susunan DNA Melayu, Humaniora Kompasiana, Jakarta, 2001.

9. -, Tekanan, Suhu dan Kelembaban Udara di Indonesia, Yahoo Indonesia Answer, 2007. 